\title{
Abstracts
}

This section of the JouRNAL is published in collaboration with two abstracting fournals, ABSTRACTS OF WORLD Medicine and Ophthalmic Literature, published by the British Medical Association. The abstracts are divided into the following sections:

Syphilis (Clinical, Therapy, Serology, Biological False

Positive Phenomenon, Pathology, Experimental). Gonorrhoea.

Nongonococcal Urethritis and Allied Conditions.

\author{
Reiter's Disease and Allied Conditions. \\ Antibiotics and Chemotherapy. \\ Public Health and Social Aspects. \\ Miscellaneous.
}

After each subsection of abstracts follows a list of articles that have been noted but not abstracted.

\section{Syphilis, Clinical}

\section{Malignant Syphilis with Fatal Outcome (with post mortem Findings) (Syphilis maligne précoce d'évolution mortelle (avec examen anatomique)) DEGOS, R., TOURAINE, R., COLLART, P., DANIEL, F., and AUDEBERT, G. (1970) Bull. Soc. \\ franc. Derm. Syph., 77, 10}

A 46-year-old man developed a penile ulcer followed 3 weeks later by right inguinal adenitis. Darkground examinations were repeatedly negative and he was given $2 \mathrm{~g}$. pristinamycin daily for 5 days; a skin rash then developed which led to his admission to the Hôpital Saint-Louis, Paris.

The skin lesions were large red infiltrated papules $2-3 \mathrm{~cm}$. in diameter which rapidly underwent central necrosis and became covered with blackish crusts. They were painless and predominated on the front of the thorax and along the paravertebral gutters. There were no lesions of the palms, soles, or mucous membranes. The chancre, which was situated on the edge of the prepuce, was ulcerated and gangrenous and surrounded by an erythematous areola. There was marked right inguinal adenitis and periadenitis. Repeated darkground examination of the chancre, skin lesions, and inguinal gland failed to show treponemes. Serological tests, including the TPI and FTA tests, were negative.

At first, penicillin $2 \mathrm{~g}$. daily was given by mouth for 7 days, but when the possibility of malignant syphilis was raised, this was changed to 1 megaunit benethamine and sodium penicillin intramuscularly each day and corticosteroids by infusion. The patient's condition deteriorated rapidly and he died 3 days later.

At post mortem, motile treponemes were seen in material from the inguinal gland but failed to infect a rabbit or mice. Treponemes were also seen in silver-stained smears from the spleen. The most marked histological change appeared to be a diffuse vascular lesion progressing from fibrinoid necrosis of the intimal walls to an obliterative thrombosis. Very few plasma cells were seen in the cellular infiltrates; this had also been noted in a biopsy of a skin lesion.

This appears to have been an example of the type of malignant syphilis described by Queyrat. No explanation of its fatal course was obvious, but it was noted that the patient weighed only $49 \mathrm{~kg}$. and was a chronic alcoholic.

\section{A. E. Wilkinson}

Neuro-ophthalmologic Study of Late Yaws and Pinta SMITH, J. L., and ISRAEL, C. w. (1970) Trans. Amer. ophthal. Soc., 68, 292

\section{Orbital Apex Syndrome and} Syphilitic Meningo-Encephalitis [In French] VALENTIN, L., VIRIEU, R., DUMAS, M., and COLLOMB, H. (1970)

Rev. Oto-neuro-ophtal., 42, 482

2 figs, 6 refs
A case is reported of the orbital apex syndrome which was due to syphilitic meningo-encephalitis and syphilitic periostitis of the orbital apex.

N. Galloway

Clinical, Immunochemical, and Serological Studies of Dementia Paralytica SCHMIDT, H., DEIN, E., RASMUSEN, E. B., and CLAUSEN, J. (1971) Int. Arch. Allerg., 40, 851 1 fig., 20 refs

Luetic Stenosis of the Abdominal Aorta and of the Renal Arteries [In Polish] RYKowsKI, H., and LEWICKI, z. (1970) Pol. Tyg. lek., 25, 694

Manifestations of Late Congenital Syphilis. An Analysis of 271

Patients fiumara, N. J., and LESSELL, S. (1970) Arch. Derm., 102, 78

The Relationship of Syphilis to Primary Carcinoma of the Tongue MEYER, I., and ABBEY, L. $M$. (1970) Oral Surg., 30, 678

Symptomatology of Tabes Dorsalis Now and in the Past [In Polish] Jakimowicz, w., HUCZYNSKI, J., and RATAJ, R. (1970)

Pol. Tyg. lek., 25, 1253

Syphilis in Pregnant Women and Newborns [In Italian] MARAGLIANO, G. (1970) Minerva Ginec., 22, 633 
Importance of the Increasing Incidence of Syphilis in Ophthalmology [In Hungarian] PÁL, M., BÖGI, J., and VÉRTES, B. (1971) Szemészet, 108, 1066 refs

\section{Syphilis, Therapy}

\section{Remote Results of Treatment of Children born to Mothers with Syphilis or with a History of} Syphilis [In Russian] POCHKHUA, P. E. (1970) Vestn. Derm. Vener., 44, 58

\section{Syphilis, Serology}

\section{Characteristics of Fluorescein- labelled Antiglobulin Preparations that may affect the Fluorescent Treponemal Antibody-Absorption Test HARDY, P. H., and NELL, E. E. (1971) Amer. F. clin. Path., 56, 181}

The usual method of finding the titre of antiglobulin conjugates for use in the FTA-ABS test is to test doubling dilutions of the conjugate against films of Treponema pallidum sensitized with a 1 in 5 dilution of strongly reactive serum in buffered saline. The working titre (WT) is taken as half the greatest dilution of conjugate which gives maximal fluorescence.

The authors, working at the Johns Hopkins University School of Medicine, have shown that the strength of the positive serum may influence the WT so determined. This may affect the reproducibility of the FTA-ABS test when different conjugates are used. They recommend that a full checkerboard titration be carried out, in which doubling dilutions of conjugate are tested against doubling dilutions of the positive serum. Through a series of dilutions of conjugate the same serum titre is reached; beyond this dilution, the 'plateau end-point' (PEP), further dilution of conjugate results in a progressive fall in the serum titre. Conjugates should be used at their PEP. The results of FTA-ABS tests on fourteen sera with two conjugates of widely differing potency are shown. When used at their PEP, the results were identical, whereas when used at the WT, the results showed some discrepancies.

\section{A. E. Wilkinson}

[Reprinted from Abstracts on Hygiene, by permission of the Editor.]

\section{Atypical Fluorescence in the Fluorescent Treponemal- Antibody-Absorption Test related to Deoxyribonucleic Acid Antibodies KRAUS, S. J., HASERICK, J. R., LOGAN, L. C., and BULLARD, J. C. (1971) f. Immunol., 106, 1665}

Sera from patients with lupus erythematosus (LE) may give atypical results in the FTA-ABS test. Some give a beaded pattern of staining of treponemes, while in others the fluorescence is homogeneous as is found in reactions with syphilitic sera. 33 sera from patients with LE were studied at the Venereal Disease Research Laboratory, Center for Disease Control, Atlanta, Ga., U.S.A. Thirteen gave beaded and ten homogeneous fluorescence, and ten produced no staining of treponemes in the FTA-ABS test.

Tests with monospecific conjugates showed that IgG was responsible for the homogeneous staining. IgG could also be detected in all of the thirteen sera giving beaded staining, IgM in six and IgA in three. With some sera the type of fluorescence was affected by the diluent; four sera which showed beading at a dilution of 1 in 5 in sorbent gave homogeneous staining at the same dilution in saline. A further serum gave homogeneous staining at a dilution of 1 in 5 in saline but showed beading at a dilution of 1 in 320 .

Reactivity in LE cell, antinucleoprotein, and anti-DNA tests was significantly greater in the sera which gave beading staining than in those which gave homogeneous or no fluorescence. When sera were treated with nucleoprotein or DNA, fluorescence was abolished with seven of nine sera which had previously given beaded staining and in two it became homogeneous. Seven LE and five syphilitic sera which gave homogeneous staining were not affected by this treatment. Exposure of the Treponema pallidum antigen used in the test to DNA-ase also abolished beaded staining in three LE sera and con- verted it to the homogeneous type in one. The authors think that an antiDNA antibody is responsible for beaded staining by LE sera and that it is more likely to be present when the disease is active. A different antibody is thought to be responsible for the homogeneous type of staining; this is not easy to differentiate from the same type of staining given by syphilitic sera. These are usually frankly positive in the FTA-ABS test, but most LE sera are said to give only borderline reactions.

A. E. Wilkinson

\section{Testing of Blood Donors for}

Syphilis GARNER, M. F., and

BACKHOUSE, J. L. (1971) Med. F.

Aust., 1, $1374 \quad 12$ refs

Polystyrene Latex used for VDRL Test [In Polish, English Summary] KOSMIDERSKI, S., BURCZEK, R., and polaK, s. (1971) Pol. Tyg. lek., 26, 1696

\section{Syphilis, Pathology}

\section{Foetal Growth with Congenital} Syphilis. A Quantitative Study NAEYE, R. L. (1971) Amer. f. clin. Path., 55, 2283 figs, 7 refs

Infections occurring in the early gestational period are recognized as causing retardation of foetal growth. The effects of congenital syphilis on antenatal growth were investigated at the Department of Pathology, Pennsylvania State University College of Medicine.

Autopsy material from 36 newborn syphilitic infants was compared with that of 36 uninfected control infants of similar gestational age, which ranged from 25 to 40 weeks. The demonstration of Treponema pallidum in the tissues, using Levaditi's stain, established the diagnosis in the cases of the syphilitic infants. Cases in which nonsyphilitic foetal or maternal disorders might have affected foetal growth were excluded.

Techniques used in measuring body, organ, and cellular growth are described. The body measurements and organ weights in the infected infants were almost normal, apart from the liver and spleen which were overweight. The numbers of paren- 
chymal cells in all organs examined were normal or nearly normal. An increased amount of haematopoietic tissue, inflammatory cells, connective tissue, and oedema accounted for almost all the hepatic enlargement. In the case of the spleen, the enlargement was due to an increase of haematopoietic tissue and erythrocytes.

In spite of considerable evidence of tissue necrosis, the author concludes that congenital syphilis does not have a significant effect on foetal body and organ growth. Possible reasons for this are discussed.

\section{S. Ratnatunga}

\section{Syphilis, Experimental}

\section{Natural Treponemal Infection in} Baboons in Casamance $(\mathrm{La}$ tréponématose naturelle ouverte du singe Papio papio en Casamance) BAYLET, R., THIVOLET, J., SEPETJIAN, M., NOUHOUAY, Y., and BAYLET, $M$. (1971) Méd. Afr. noire, 18, 799 Sera from 82 baboons captured in the Casamance area of Senegal were examined by a quantitative FTA test against Treponema paliidum as antigen. 52 were positive at titres of 200 or above; in thirty sera the titres ranged from 1600 to 51200 .

Specimens of fluid from lymph nodes or from the eyes of ten animals were examined for treponemes by silver staining and by immunofluorescence staining; none was found. Hamsters inoculated with material from these animals did not develop any lesions and TPI and FTA tests on them remained negative.

Three baboons captured in areas where yaws is prevalent developed crusted ulcerative lesions round the mouth or on the face and in the axilla. The FTA test was positive at a high titre in all three animals. The lesions contained treponemes which were morphologically similar to $T$. pallidum and $T$. pertenue. Attempts to infect experimental animals were successful with only one strain. This produced ulcerated lesions in hamsters at the site of inoculation in 6 months; with successive transfers this shortened to 38-47 days. No lesions developed in mice, but one guinea-pig developed a scrotal lesion containing treponemes 4 months after inoculation. Rabbits are also apparently susceptible to infection. This pattern of host susceptibility is said to be identical to that of a strain of treponemes isolated from patients with endemic (nonvenereal) syphilis in Senegal.

A. E. Wilkinson

[Reprinted from Abstracts on Hygiene, by permission of the Editor.]

\section{Gonorrhoea}

Recovery of Neisseria gonorrhoeae from 'Sterile' Synovial Fluid in Gonococcal Arthritis HOLMES, K. K., GUTMAN, L. T., BELDING, M. E., and TURCK, M. (1971) New Engl. f. Med., 284, 318

A 32-year-old woman complained of a painful swollen left wrist. There were no general symptoms except for slight fever $\left(99^{\circ} \mathrm{F}\right.$.). Gonococci were grown from the cervix and anus but blood cultures were sterile. Fluid from the wrist contained many neutrophils, but no gonococci were seen in Gram-stained smears. The patient was treated with 10 mega units penicillin $G$ intravenously over 24 hours, followed by $2 \mathrm{~g}$. oral ampicillin daily for 10 days, with rapid relief of symptoms.

Fluid from the wrist was inoculated on to chocolate agar, Thayer-Martin medium, and an agar overlay medium. This last consisted of Trypticase Soy Broth with 10 per cent. sucrose, 20 per cent. horse serum, and 1.25 per cent. agar. After inoculation the plate was overlaid with $0.5 \mathrm{ml}$. of the same medium containing half the concentration of agar. No growth occurred on the chocolate agar or Thayer-Martin media after 96 hours. The overlay medium showed a scanty growth of oxidase-positive colonies after 72 hours. Some grew only into the overlay; others showed a peripheral zone of growth resembling reverting Lform colonies and contained Gramnegative diplococci. These grew as tiny colonies on subculture to chocolate agar and were identified as gonococci by fluorescent antibody staining and fermentation reactions.

\section{A. E. Wilkinson}

Gonococcal Vulvovaginitis and

Possible Peritonitis in

Prepubertal Girls BURRY, v. F.

(1971) Amer. F. Dis. Child., 121, 536

5 refs

Four girls with gonococcal vulvovaginitis and clinical evidence of peritonitis were seen between 1963 and 1970 at the Children's Mercy Hospital, Kansas City, Missouri. One was aged 10 years and the others all 6 years. Response to penicillin was dramatic. They represented 10 per cent. of the young girls with gonococcal vulvovaginitis seen at the same hospital during the same period. In view of the general increase of gonorrhoea in the adolescent and adult population, the condition may become more common in children in the future.

P. Rodin

\section{Treatment of Gonorrhoea with Aqueous Benzyl Penicillin plus} Probenecid NIORDSON, A.-M., and ullman, s. (1971) Acta derm.venereol. (Stockh.), 51, 311

The results are analysed of the treatment of 219 men and 179 women with gonorrhoea attending the Rigshospitalet, Copenhagen. 57 were given 1 mega unit aqueous benzyl penicillin plus 1.2 mega units aqueous procaine penicillin in one injection. Six patients were not followed up, five relapsed, and three were judged to have been re-infected. All of those who relapsed harboured strains of gonococci with diminished sensitivity to penicillin (M I C $\geqslant 0.053$ unit $/ \mathrm{ml}$.). The incidence of such strains among the 398 patients was 22 per cent. A further 186 men and 155 women were given $1 \mathrm{~g}$. probenecid by mouth followed 30 minutes later by a single injection of 5 mega units aqueous benzyl penicillin. Nineteen patients were not followed up, eleven relapsed (nine carrying insensitive strains), and eleven were re-infected. Ten men and thirteen women had positive cultures from the rectum alone; none of these relapsed after treatment.

\section{A. E. Wilkinson}

[Reprinted from Abstracts on Hygiene, by permission of the Editor.] 
Oral Ampicillin in

Uncomplicated Gonorrhoea. III. Results of Treatment in Women with Positive Rectal Cultures ERIKSSON, G. (1971)

Acta derm.-venereol. (Stockh.), 51, 305 This report compares various treatments of rectal gonorrhoea in women attending the Söderssjukhuset, Stockholm. The diagnoses were confirmed by culture. In 1967-68, rectal cultures were positive in 268 of 846 patients. These were treated with 1 mega unit sodium penicillin $G$ plus 1.2 mega units procaine penicillin in a single injection. In 1968-69 there were 370 positive rectal cultures in 936 patients. These were randomly allocated to three forms of treatment:

(a) $2 \mathrm{~g}$. ampicillin by mouth;

(b) 2 g. ampicillin plus $1 \mathrm{~g}$. probenecid by mouth;

(c) two doses of $1 \mathrm{~g}$. ampicillin by mouth with an interval of $5 \mathrm{hrs}$ between them.

Sensitivity studies were performed by a disc method and 23.3 and 26.5 per cent. of the strains isolated in the two years were classed as insensitive to penicillin (M I C $\geqslant 0.1 \mathrm{unit} / \mathrm{ml}$.).

The results of the trial are analysed in considerable detail. Patients whose cultures from any site (urethra, cervix, or rectum) were found positive on follow-up within 14 days were classed as treatment failures. This occurred in 5 per cent. after penicillin, 7.6 per cent. after a single dose of ampicillin, 0.9 per cent. after ampicillin plus probenecid, and 2.5 per cent. after ampicillin in divided dosage. A comparison of the results in patients with and without positive rectal cultures showed that penicillin was significantly less effective when the rectal culture was positive; this was not apparent with the various treatments with ampicillin.

For routine treatment, ampicillin in divided dosage is recommended. If it is thought likely that the patient may not take the second dose, ampicillin plus probenecid in a single dose should be given. A. E. Wilkinson

[Reprinted from Abstracts on Hygiene, by permission of the Editor.]

\section{Comparative Study of} Gonococcal Susceptibility to Penicillin in the United States, 1955-1969 MARTIN, J. E., JR.,
LESTER, Z., PRICE, E. v., and SCHMALE, J. D. (1970) F. infect. Dis., 122, 459 [From the Venereal Disease Research Laboratory, Center for Disease Control, Atlanta, Georgia]

During the first 10 years after the introduction of penicillin therapy for gonorrhea, in vitro susceptibility testing of 771 gonococcal isolates in the United States revealed that only five cultures ( 0.6 per cent.) required more than $0.05 \mathrm{unit} / \mathrm{ml}$. penicillin to inhibit the organism. Susceptibility testing of 1,124 cultures isolated in 1965 from routine clinic admissions in seven cities indicated that during the second 10 -year interval the cultures requiring more than $0.05 \mathrm{unit} / \mathrm{ml}$. penicillin to inhibit growth increased from 0.6 to 42 per cent. Five per cent. of the cultures tested required more than 0.5 unit $/ \mathrm{ml}$. for complete inhibition. The most recent testing of susceptibility (1968-69) of 649 cultures isolated from a comparable population in five cities demonstrates a continued increase in gonococcal resistance to penicillin. Since 1965, the percentage of isolates requiring more than 0.05 unit $/ \mathrm{ml}$. to inhibit growth has increased to 65 per cent., and the number of cultures requiring 0.5 unit $/ \mathrm{ml}$. has almost tripled. Studies of 108 gonococcal isolates from patients in whom penicillin treatment failed since 1965 have shown an even greater increase in resistance. Authors'summary

\section{Transfer of Gonococcal \\ Urethritis from Man to \\ Chimpanzee LUCAS, C. T., CHANDLER, F., MARTIN, J. E., and}

SCHMALE, J. D. (1971) F. Amer. med. Ass., 216, 1612

Urethral exudates from three sets of five males with bacteriologically proven gonococcal urethritis were pooled in $0.5-\mathrm{ml}$. amounts of trypticase soy broth. This was introduced by a catheter for a distance of $7 \mathrm{~cm}$. into the urethra of each of three male chimpanzees under anaesthesia. Smears and cultures were obtained from the urethra, rectum, and oropharynx of each animal at intervals up to 30 days.

A small amount of exudate was seen after stripping the urethra on the 4th day. Discharge was apparent clinically from the 7 th to the 14th day, after which it diminished and was virtually absent by the 30th day. Urethral smears and culture showed the presence of gonococci on all occasions. Those from other sites were negative, except that one animal developed a unilateral conjunctivitis on the 25th day; gonococci were found by smear and culture from this lesion which was presumably due to autoinoculation. Urethral exudate was collected from two animals on the 10th day and transferred to a fourth chimpanzee. Infection in this animal followed a similar course to that in the other three.

Complement-fixation tests on sera with lyophilized crude gonococcal protoplasm as antigen showed that antibody was detectable on the 14th, 15th, 20th, and 25th day after infection in the four animals. The titres rose from 1 in 16 to 1 in 64 .

These well-controlled tests show that the chimpanzee provides an animal model for the experimental study of gonorrhoea. A.E. Wilkinson

Culture of Neisseria gonorrhoeae on Egg-enriched Media [in Polish] PEKOWSKI, H., and SZYSZYMAR, B. (1971) Przegl. Derm., 58, 2731 fig., 7 refs

From the Bacteriological Laboratory of the Provincial Dispensary for Skin and Venereal Diseases in Bydgoszcz the results are reported of a study evaluating two different egg media for the isolation of the gonococcus. The following media were used:

(1) Roiron's agar medium with a suspension of hens' eggs replacing horse serum;

(2) Löwenstein-Jensen glycerol-egg medium as used for the cultivation of the tubercle bacillus, which the authors modified by the addition of sodium phosphate $\left(\mathrm{Na}_{2} \mathrm{HPO}_{4}\right)$ to raise the $\mathrm{pH}$ from 6.5 to 7.4 and the exclusion of malachite green to eliminate its inhibitory effect on the gonococcus;

(3) Roiron's agar medium with horse serum, as a control.

The media were inoculated directly with the urethral discharge from thirty men (29 positive by smear) and urethral and cervical secretions from twenty female contacts (nine positive by smear).

The gonococcus was isolated from all thirty men and from fourteen of the women by all three cultural methods. 
The colonies were equally as abundant on the two egg media as on the medium with horse serum. On the modified Löwenstein-Jensen medium, the growth of concomitant Grampositive organisms (mostly Streptococci and Stahpylococci) was less plentiful than on the agar media which facilitated the identification of gonococcal colonies, particularly in women. Simplicity of preparation and low cost are other advantages of this medium with special appeal to the small laboratory.

L. Z. Oller

Ampicillin in the Treatment of Gonococcal Salpingitis [in Swedish] HEDBERG, E., and JONASSEN, F. (1971) Svensk. Läk.-Tidn., 68, 335

One-day Oral Ampicillintreatment of Gonorrhoea in Young Adults SHAPIRO, L. H., LYNN, D. R., and DIGIACOMO, A. M. (1971) Obstet. and Gynec., 37, 414

Cephalexin in the Oral Treatment of Gonorrhoea by a Double-dose Method willcox, R. R., and woodcock, K. s. (1970) Postgrad. med. F., 46, Suppl. 103

Sensitivity of the Gonococcus to Penicillin [in Dutch] wols-vander WIElEN, A. (1970) Ned. T. Geneesk., 114, 1690

Asymptomatic Gonorrhoea in Prenatal Patients Charles, A. G., COHEN, S., KASS, M. B., and RICHMAN, R. (1970) Amer. F. Obstet. Gynec., 108, 595

Migratory Arthralgias and Cutaneous Lesions as Confusing Initial Manifestations of Gonorrhoea WHEELER, J. K., HEFFRON, W. A., and WILLIAMS, R. C. (1970) Amer. F. med. Sci., 260, 150

\section{Atypical Case of Gonococcal}

Bacteraemia [in Danish]

JACOBSEN, M., and TIDSTROM, B. (1971)

Ugeskr. Laeg., 133, 6

Gonococcal Meningitis TAUBIN, H. L., and LANDSBERG, L. (1971) New Engl. F. Med., 285, 5049 refs
Meningococcus and Gonococcus ${ }_{4}$ Never the Twain ... Well, Hardly Ever FELDMAN, H. A. (Editorial) New Engl. J. Med., 285, 5187 refs

\section{Gonococcal Arthritis in an}

Adolescent Girl BREWER, G. F., DAVIS, J. R., and GROSSMAN, M. (1971)

Amer. F. Dis. Child., 122, 25311 refs

Gonococcal Arthritis KUSHNER, I. (1970) Med. Times, 98, 111

Specific and Non-specific Immunofluorescent Reactions shown by Different Preparations of FITC-labelled Rabbit

Antigonococcal Globulin LIND, I., and RHODES, J. M. (1970) Acta path.

microbiol. scand., 78, 153

\section{Nongonoccal urethritis and allied conditions}

\section{Endocervical Neisseria} meningitidis with

Meningococcaemia KEYS, T. F., HECHT, R. H., and CHOW, A. W. (1971) New Engl. F. Med., 285, 5052 refs The increasing incidence of gonorrhoea in the United States and elsewhere has alerted physicians to suspect this disease when patients are seen with fever, rash, and polyarthritis. Two cases are described which demonstrate the difficulty in clinically distinguishing disseminated gonorrhoea from infection caused by the meningococcus. Both were women and had fever and arthritis. One had haemorrhagic vesicular lesions and the other an erythematous rash over the involved joints. In one case Group C meningococci were isolated from blood, joint, and endocervical cultures and in the other Group W-135 meningococci from the endocervix only.

The patients may have had primary meningococcal infection of the cervix with blood-stream dissemination to skin and joints, but it is possible that the organism may have reached the cervix via the bloodstream. One attempt to culture meningococci from the urethra of one contact was unsuccessful.

P. Rodin

Rheumatoid Arthritis in a Gorilla BROWN, MCP. T., CLARK, H. W., BAILEY,
J. S. and GRAY, C. W. (1970) Trans. Amer. clin. climat. Ass., 82, 227

A gorilla kept in a zoo developed rheumatoid arthritis with positive rheumatoid factor. A large-colony mycoplasma was isolated from the synovial tissue and other sites and the disease appeared to respond to very large doses of tetracycline and lincomycin; when the dose of the antibiotics was reduced, disease activity increased. The naturally-occurring arthritis in this animal is considered to be a valid model for the human disease.

G. W. Csonka

\section{A Study of Candida in 1,007}

Women ANYON, C. P., DESMOND, F. B., and EASTCOTT, D. F. (1971)

N.Z. med. F., 73, 920 refs

This paper from the research group of the Wellington Faculty of the Royal College of General Practitioners reports the prevalence of Candida in the vagina and rectum in a normal urban female community in New Zealand. Any woman attending the surgeries of general practitioners in a specified area during the period of study on whom a vaginal examination was performed was included in the study.

Vaginal and rectal specimens were taken on cotton-tipped applicators and sent to the laboratory in Stuart's transport medium. Identification of Candida albicans was made by chlamydospore formation on rice-extract agar and germ-tube formation in sterile human plarma; Candida species other than albicans were isolated from 45 patients.

Candida was isolated from the vagina in 194 (19.3 per cent.) of the 1007 patients and from the rectum in 170 (17.2 per cent.). There was a significantly higher rate of isolation from the vagina among those under 40 than among those over 40 years of age. Isolations from the rectum showed no such difference. A significant decrease in isolations from both the vagina and the rectum was noted in the post-natal period.

While there was no significant difference in isolations of Candida from women taking different brands of anovulants, there was a significant increase in isolations from women taking an oestrogenic pill.

It was also observed that while 
there was a significantly greater number of isolations of Candida from the vagina among those who had taken antibiotics in the previous 3 months than among those who had not, there was no such difference in isolations from the rectum in the two groups. Reasons for these findings are discussed. C.S. Ratnatunga

\section{Serological Methods for \\ Classification of Human \\ T-Mycoplasmas BLACK, F. T. (1970) V. Int. Congr. Infect. Dis., Vienna, 1, 4096 figs, 6 refs}

Seven human $\mathrm{T}$-mycoplasmas were tested by the metabolic inhibition test, the growth inhibition test, the indirect immunofluorescence test, and the indirect haemagglutination test. The results of three additional serological methods confirmed that at least seven serotypes exist amongst human $\mathrm{T}$-mycoplasmas as previously found on the basis of the metabolic inhibition test alone. Growth inhibition test and the indirect immunofluorescence test were applied to twelve $T$-strains isolated from patients with non-gonococcal urethritis; both methods gave identical results showing also that these strains are of different serotypes. Two of the isolates could not be identified by means of the seven available antisera. A new type designation of human $\mathrm{T}$-mycoplasmas is proposed. G. W. Csonka

\section{Epididymitis in Children}

HAAHR, J., and SPARREVOHN, S. (1971) Acta paediat. scand., 60, 216 figs, 16 refs

Epididymitis before puberty is rare. In prepubertal boys, acute scrotal lesions are usually due to torsion of the testis or incarcerated hernia. In a 4-year period six cases of epididymitis in children were seen at Glostrup Hospital, Denmark. In two cases, the condition formed part of Schönlein-Henoch's purpura and in each case biopsy from the epididymis showed changes characteristic of this disease. In one case the epididymitis was suppurative in nature and in one it represented a complication of orchidopexy. In the remaining two cases the cause was obscure. Infection of the urinary tract was not observed in any of the patients and the urinary tract was normal in all except one of the children with Schönlein-Henoch's purpura who had a bifid pelvis on one side.

P. Rodin

Immunological Reactivity to

Mycoplasma fermentans in

Patients with Rheumatoid

Arthritis williams, M. H., and BRUCKNER, F. E. (1971) Ann. rheum. Dis., 30, 271

Meningococci in Vaginitis GREGORY, J. E., and ABRAMSON, E. (1971) Amer. F. Dis. Child., 121, 423 3 refs

Clinical and Laboratory Study of Monilial Vaginitis NAGESHA, C. N., and ANANTHAKRISHNA, N. C. (1970) Amer. F. Obstet. Gynec., 107, 1267 1 fig., 2 refs

\section{Urease Colour Test Medium U-9} for the Detection and

Identification of ' $T$ ' $M y c o p l a s m a s$ in Clinical Material SHEPARD, M. C., and LUNCEFORD, C. D. (1970) Appl. Microbiol., 20, 539

MK-915, a New Preparation for the Oral Treatment of Trichomonal Colpitis [In

German] LIECHTI, R. (1970)

Schweiz. med. Wschr., 100, 2117

\section{Reiter's disease and allied conditions}

Complement-fixing Antibodies to Bedsonia in Reiter's Syndrome, TRIC Agent Infection, and Control Groups SCHACHTER, J. (1971) Amer. f. Ophthal., 71, 857 7 refs

Positive complement-fixing tests to Bedsonia were found in a higher proportion of patients with Reiter's syndrome and TRIC infection compared with controls. The author concludes that the findings may suggest a causal relationship in Reiter's syndrome. Redmond Smith

Diagnosis of Conjunctivitis in the Feissinger-Leroy-ReiterSyndrome [In German] REICH, H., and JüNEMANN (1971) Klin. Mbl. Augenheilk., 159, 198
Reiter's Disease [In Dutch] BLÉCOURT, J. J. DE (1971) Ned. T. Geneesk., 115, 97

Reiter's Disease [In German] FANTA, D., et al. (1971) Wien. klin. Wschr., 83, 841

Search for Mycoplasma in Rheumatoid Arthritis JANSSON, E., VAINIO, U., SNELLMAN, O., and TUURI, s. (1971) Ann. rheum. Dis., 30, 4136 figs, 26 refs

\section{Antibiotics and chemotherapy}

Penicillin Allergy: A Review of Immunological and Clinical Aspects ISBISTER, J. P. (1971) Med. F. Aust., 1, 1067 1 fig., 59 refs

Cephaloridine and Cephalexin in Venereological Practice OLLER, L. Z., SMITH, H. G., and MARSHALL, M. J. (1970) Postgrad. med. F., 46, Suppl. 99

\section{Public health and social aspects}

Non-Venereal Treponematosis in Colonial North America PARRAMORE, T. C. (1970) Bull. Hist. Med., 44, 571

Seasonality of Gonorrhoea in the United States CORNELIUS, C. E. (1971) HSMHA Health Rep., 86, 157

Venereal Diseases. A Study of the Attitudes towards and Knowledge of them among Young People [In Swedish] WALLIN, J. (1971) Svensk. Läk.-Tidn., 68, 199

Endemic and Venereal Syphilis. Diseases of Civilization

(Syphilis endémique, syphilis vénérienne. Maladies de la civilisation) TISSEUIL, J. (1971)

Bull. Soc. Path. exot., 64, 296

11 refs 
Venereal Disease in the Department of the Rhone, 1969 (Les maladies vénériennes dans le Rhône en 1969) THIERS, H., KADI, M., and RACOUCHOT, J. (1971) Bull. Soc. franf. Derm. Syph., 78, 204

\section{Serological and Parasitological Study of the Indigenous Populations of the Republic of Rwanda I. Serological Study.} Frequency of Syphilis (Enquête sérologique et parasitologique dans les populations autochtones de la Republique du Rwanda. I. Résultats de l'enquête sérologique. Fréquence de la syphilis) BIEMANS, B., BUTERA, S., CIRERA, P., and LARROURY, G. (1971) Bull. Soc. Path. exot., 64, $277 \quad 1$ fig., 19 refs

Frequency of Treponematoses in Certain Populations of the Agadès Department in the Niger Republic (Sur le fréquence des tréponématoses dans certaines populations du Départment d'Agadès (République du Niger)) CIRERA, P., LEFEVRE-WITIER, P., and TREILHOU, J-P. (1971) Bull. Soc. Path. exot., 64, 2915 refs

Venereal Infection in the Elderly KRISHNAN, M. v., and LOMAX, w. (1970) Geront. Clin., 12, 76

\section{Miscellaneous}

Resurgence of Scabies ORKIN, M. (1971) F. Amer. med. Ass., 217, 593 3 figs, 14 refs

This study on the current status of scabies is based upon information obtained from a survey form completed by 86 American and 73 foreign dermatologists and a comprehensive review of the world literature. Although the disease became uncommon in the 1950s, there has been since 1963 and 1964 a progressive increase in scabies in many parts of the world, to epidemic proportions in some areas. The epidemic has not yet involved the United States or Canada, except for sporadic outbreaks and small foci (mainly hippies). The cause of this recent resurgence is not clear; demographic and immunologic considerations seem particularly worthy of further study. Author's summary
New Methods of treating Virus Infections of the Skin (Neue Methoden in der Behandlung von Virus Infektionen der Haut) söLTZ-SZÖTs, J. (1971) Z. Haut-u. Geschl.-Kr., 46, 7554 figs, 28 refs 532 patients with recurrent herpes, including genital herpes, were treated by vaccination with herpes simplex antigen and re-vaccination at 3 to 6monthly invervals. Details of the vaccine are not given but, as it contains traces of protein, allergic reactions may occur and treatment should be undertaken in appropriate departments. 77.8 per cent. of those treated had no relapses. Local treatment with iododeoxyridine was disappointing. Another method of treating virus infection is by stimulating interferon production by the host by vaccination with inactivated influenza $A$ vaccine. This appeared to reduce the duration of herpes zoster from an average of 31 days in the untreated cases to 17 days in the vaccinated group. This treatment is being evaluated in a large group of patients with recurrent herpes simplex. G. W. Csonka

\section{Genital Herpes in Two Social}

Groups RAWLS, W. E., GARDNER, H. L., FLANDERS, R. W., LOWRY, S. P., KAUFMAN, R. H., and MELNICK, J. L. (1971) Amer. F. Obstet. Gy'nec., 110, 6827 figs, 20 refs

Genital herpes was studied in two social groups. Among Caucasians of the upper socioeconomic class with clinical primary genital herpes, 78 per cent. had no antibodies to either Type 1 or Type 2 herpesvirus in their initial serum samples. Among the Negroes of the lower socioeconomic class with primary genital herpes, only 29 per cent. had no antibodies initially. There was no difference in subsequent antibody response in the two groups. Fourteen of eighteen female sexual contacts of men with genital herpes showed evidence of herpesvirus Type 2 infection, further supporting the view that genital herpes is primarily a venereal disease. G. W. Csonka

\section{Articular Manifestations of}

Behçet's Syndrome (Les manifestations articulaires de l'aphtose (syndrome de Behçet))
BISSON, M., AMOR, B., KAHAN, A., and delbarre, f. (1971) Sem. Hôp. Paris, 47, 202346 refs

This review from the Hôpital Cochin, Paris, is based on a study of sixteen patients (ten of them male) with Behçet's syndrome and arthritis. Their ages ranged from 22 to 50 years. In six cases the arthritis preceded the other manifestations by up to 3 years, and in the remainder arthritis either accompanied or followed the ulceration and the skin lesions.

As a rule only one or a few joints were affected - the knee most often, followed by ankle, wrist, elbow, and shoulder in that order. In most patients the disorder ran a relapsing course, with symptoms persisting for up to a month and recurring at intervals, sometimes for years. In spite of this there was little permanent damage to the affected joints and there were no $x$-ray changes. Nonspecific blood changes were noted; the ESR was often raised ( $>50 \mathrm{~mm}$. in $1 \mathrm{hr}$ ) and there were sometimes mild anaemia and leucocytosis. There was often some increase in $x$-globulin and IgG levels: the Waaler-Rose and LE cell tests were negative.

The synovial fluid contained a high cell count, predominantly polymorphonuclears, and ragocytes were seen in ten of eleven preparations examined. The inclusion bodies were large and did not suggest virus particles in appearance, nor were viruses grown on culture. Complement levels were raised in synovial fluid. Biopsy studies of synovial tissue showed villous hypertrophy and nonspecific histological changes.

Ulceration was present in the mouths of all sixteen patients and on the genitalia of twelve. There was a variety of skin lesions, suggestive of erythema nodosum in nine. Three had conjunctivitis and two iridocyclitis. Four had diarrhoea.

An attempt at treatment by desensitization was made by giving a series of injections of autologous saliva, diluted $1: 10$, with benefit in four out of five patients so treated. The most effective treatment, however, in the short-term appeared to be corticosteroids, though relapses followed.

F. A. Cosh 
Recurrent Aphthous Stomatitis and Behçet's Disease FRANCIS T. C. (1970) Oral Surg., 30, 476 85 refs

Behçet's Syndrome with a Cryoparaprotein FIDDES, P. J., and PENNY, R. (1971) Med. f. Aust., 1, 12752 figs, 16 refs

\section{Anal Soft Chancre and Concomitant Gonorrhoea (Chancre mou anal et gonoccie concomitante) RIVOIRE, M. J. (1971) Bull. Soc. franc. Derm. Syph., 78, 203}

Herpes Simplex Virus and Cancer of the Cervix Plummer, G., and MASTERSON, J. G. (1971) Amer. $\mathcal{F}$. Obstet. Gynec., 111, 81 1 fig., 17 refs

Size, Composition, and Structure of the Deoxyribonucleic Acid of Herpes Simplex Virus Subtypes 1 and 2 KIEFF, E. D., BACHENHEIMER, S. L., and ROIZMAN, B. (1971)

f. Virol., 8, 1255 figs, 31 refs

Type-specific Surface Antigens of Cells infected with Herpes Simplex Virus (1 and 2)

NAHMIAS, A. J., DELBUONO, I., SCHNEWEIS, K. E., GORDON, D. S., and THIES, D. (1971) Proc. Soc. exp. Biol. (N.Y.), 138, 21
Genital Herpes and Cervical Cancer [In Finnish] LEINIKKI, P., and VAHERI, A. (1971) Duodecim, 87, 181

Optic Neuritis and Compressive Neuropathy associated with Cat Scratch Disease SWEENEY, v. P., and DRANCE, S. M. (1970) Canad. med. Ass. F., 103, 13804 refs

Advances in the Treatment of Sexually Transmitted Diseases CATTERALL, R. D. (1971)

Practitioner, 207, 516

\section{M.S.S.V.D. Library}

On June 1, 1971, the Society purchased the following books from the estate of the late Dr. A. N. Harkness.

A Treatise of all the Degrees and Symptoms of the Venereal Diseases in both Sexes. Sixth Edition

An Attempt to Simplify the Treatment of Sexual Diseases

Traitement de la Syphilis

Lues Venerea

Practical Observations on the Natural History and Cure of the Venereal Disease. Vols I and II. Second Edition

A Practical Dissertation on the Venereal Disease. Fifth Edition

Diseases of the Skin including the Exanthemata. Vol. IV

Syphilis. Second Edition

Syphilis and Local Contagious Disorders. Second Edition

Chururgical Observations on the Disorders of the Urethra

Remarks and Practical Observations on Venereal Complaints and Disorders of the Urethra

Diseases of the Joints

Engravings of Bones, Muscles and Joints $\begin{array}{ll}\text { John Marten } & 1708\end{array}$

James Thorn 1831

Alfred Fournier $\quad 1902$

John Pearson 1800

John Howard 1806

Daniel Turner $\quad 1737$

Ferdinand Hebra and Moriz Kaposi 1875

Sir Jonathan Hutchinson $\quad 1909$

Berkeley Hill and Arthur Cooper 1881

James Daran 1780

Goulard 1772

B. C. Brodie 1818

John Bell 